\title{
The Effects of Job Autonomy on Work Outcomes: \\ Self Efficacy as an Intervening Variable
}

\author{
Susanti Saragih \\ Universitas Kristen Maranatha, Bandung - Indonesia
}

\begin{tabular}{|c|c|}
\hline ARTICLE INFO & A B S T R A C T \\
\hline $\begin{array}{l}\text { Received: May } 26,2011 \\
\text { Final revision: October } 30,2011\end{array}$ & $\begin{array}{l}\text { The purpose of this research was to examine the relationship between job auto- } \\
\text { nomy and work outcomes (job performance, job satisfaction and job stress), }\end{array}$ \\
\hline $\begin{array}{l}\text { Keywords: } \\
\text { Job autonomy, } \\
\text { Job Satisfaction, } \\
\text { Job performance, } \\
\text { Job Stress, } \\
\text { Self efficacy }\end{array}$ & $\begin{array}{l}\text { self efficacy as a mediating variable. This research also investigated the impact } \\
\text { of job satisfaction on job performance and job stress on job performance. Va- } \\
\text { riables in this research were measured via a survey of } 190 \text { banking salespersons } \\
\text { in D.I. Yogyakarta and Solo. Structural Equation Modeling (SEM) were used to } \\
\text { examine the effects of job autonomy on work outcomes, job satisfaction on job } \\
\text { performance, and job stress on job performance. Results showed that the esti- } \\
\text { mated model in this research is acceptable based on its score of the goodness } \\
\text { of fit index. The structural relationship showed that job autonomy significantly } \\
\text { related to job satisfaction and performance, but not significant with job stress. } \\
\text { It also showed that self efficacy partially mediated the relationship between job } \\
\text { autonomy and job satisfaction, and job performance. In addition, this research } \\
\text { found that self efficacy not mediated the relationship between job autonomy } \\
\text { and job stress. There was no significant relationship between job autonomy } \\
\text { and job performance but this research showed that job satisfaction significantly } \\
\text { related to job performance. Finally, these results had an important implication } \\
\text { to managers in designing job. }\end{array}$ \\
\hline
\end{tabular}

(C) 2011 IRJBS, All rights reserved.

Corresponding author:

$\mathrm{P}$ revious researches have been used job autonomy to predict and test the effects of job design on work outcomes. These researches describe that job autonomy became the critical antecedent for many positive work outco- mes. Gellatly and Irving (2001), Langfred and Moye (2004) found the positive effects of job autonomy on job performance. Job autonomy enhances performance because workers with high job autonomy will perceive that he/she trusted to perform the 
task. This perceives positively effects their intrinsic motivation and the effectiveness in working.

Several researches found positive association between job autonomy and job satisfaction (DeCarlo and Agarwal, 1999; Finn, 2001; Liu et al., 2005; Nguyen et al., 2003; Thompson and Prottas, 2005). Workers that given high autonomy will fell that the results of their job are determined by their efforts, actions and decisions so, they will fell more satisfied.

Another work outcomes that related to job autonomy is job stress. Job autonomy allow individuals to limit their exposure to stressors and able to choose their task or allow individuals to limit the more stressful tasks, thereby reducing feelings of threat and encouraging positive coping behaviors (Elsass dan Veiga, 1997). Thompson and Prottas (2005) support this finding. They found that job autonomy significantly negative to job stress, turnover intention, and work and family conflict. Furthermore, Kauffeld (2006), Nonaka e al., (2000) in Smith et al. (2003) also found positive association between job autonomy and worker's competency and creativity.

Generally speaking, researches in job autonomy have showed the consistent relationship between job autonomy and work outcomes. However, research on job autonomy has left several questions unanswered. This present study focuses on question: what are the processes by which job autonomy effects work outcomes? To answer that question, this research used self efficacy as an intervening variable between job autonomy and work outcomes. According to Gist and Mitchell (1992), self efficacy is an important motivational construct. It influences individual choices, goals, emotional reactions, efforts, coping an persistence. Self efficacy also changes as a result of learning, experience, and feedback.

To the extent that autonomy is high, work outcomes will be viewed by employees as depending substantially on their own efforts, initiatives, and decisions, rather than on the adequacy of instructions from the boss or in a manual of procedures. This condition has positive effects on employees' self efficacy judgment because they perceive themselves as more capable and more resourceful thereby increasing their self efficacy (Wang dan Netemeyer, 2002). Employee with high self efficacy will put forth more effort and is more likely to persist when encountering obstacles or negative experiences (Kreitner and Kinicki, 2004).On the other hand, employee with low self efficacy is apt to give up, believing the difficulties merely prove that he or she was unable to do the job. Self efficacy also has a significant positive correlation with job satisfaction, job performance and job stress. Employees' satisfaction increases because the feeling of competence and confidence that accompany self efficacy make job the more enjoyable and able to coping the stressor in the workplace. Therefore, job design with high autonomy will be powerful in influence employees' performance, satisfaction and reduce job stress through increased self efficacy.

Finally, by setting self efficacy as an intervening variable between job autonomy and work outcomes (performance, satisfaction and job stress), this research is going to explain the process of job autonomy effects work outcomes. This study is important for the following reasons. First, it contributes to the literature by used self efficacy to explain how job autonomy effects work outcomes. Second, this study also contributes an empirical evidence in investigated the relationship within the work outcomes occurred on job autonomy, such as the effects of job satisfaction on performance and the effects of job stress on performance. Third, the results of this study may have important implications for human resource managers in designing job.

\section{Theoretical Framework and Hypothese}

Development

Job Autonomy, Self Efficacy and Job Performance
Job autonomy is defined as the degree to which the job provides substantial freedom, independence, and discretion to the individual in scheduling work and in determining the procedures to be used in carrying it out. Job autonomy is one of several core job design characteristic (the others are skill variety, task identity, task significance and feedback from the job) developed by Hackman and Oldham (1975). According to Hackman and Oldham (1975), autonomy leads to the critical a psychological state of "experienced responsibility for outcomes of the work", which in turn leads to outcomes such as high work effectiveness and high internal work motivation.

Researches in job autonomy have showed a consistent and positive association between job autonomy and performance. Gellatly and Irving (2001) found positive effect of perceived autonomy on contextual performance. Managers who report greater autonomy in their work have a better performance than managers who report lower autonomy. Claessens et al., (2004) found that perceived autonomy in time was positively related to job performance and job satisfaction and negatively to work strain. According to Langfred and Moye (2004), job autonomy enhances job performance because they perceive themselves capable and more resourceful in performing the task. Psychologically, employee will more motivate to do the best and leads to higher performance. Therefore, a positive linkage is hypothesized between job autonomy and job performance.

Hypothesis 1: Job autonomy is positively related to job performance.

A high level of autonomy as perceived by employees has sends a message that supervisor has confidence in his or her capability therefore allows the employees to carry out the task the way he or she wish to. This message has a positive effect on employees' self efficacy. Wang and Netemeyer (2002) test the effects of job autonomy and self efficacy. The result showed a positive association between job autonomy and self efficacy. The higher job autonomy leads to higher confidence in performing the task. According to Bandura (1997), this confidence will affect the effort invested to attain the best performance. Therefore, a positive linkage is hypothesized between job autonomy, self efficacy and job performance.

Hypothesis-2: Job autonomy is positively related to job performance, self efficacy as an intervening variable.

\section{Job autonomy, Self Efficacy and Job Satisfaction} Job autonomy is believed could influence job satisfaction. More autonomy is expected to be associated with greater job satisfaction because employees have more freedom to determine thei own effort and work schedule. Previous research in this area has been found the significant and consistent results. Morrison et al. (2005) explain that job autonomy became a critical factor in enhancing employees' intrinsic motivation and job satisfaction. Finn (2001) found that job autonomy became the important component in nurses' job satisfaction. Cuyper and Witte (2005) also support this finding; job autonomy is found significantly effect job satisfaction both permanent and temporaries employment. A cross cultural study by DeCarlo and Agarwal (1999) examines the effect of job autonomy on salesperson's job satisfaction. In general, this study finding suggests perceived job autonomy is an important antecedent to job satisfactions among salesperson from Australia, India and U.S. Therefore, it is hypothesized that

\section{Hypothesis-3: Job autonomy is positively related to} job satisfaction

Job autonomy will enhance employees' self efficacy because they fell they can go about job basically by themselves without much guidance, resulting in a stronger autonomy-efficacy linkage. Research indicates that high job autonomy enhances employee feelings that job outcomes are a result of his/her efforts (Wang and Netemeyer, 
2002; DeCarlo and Agarwal, 1999). In addition, the feeling of job personal responsibility leads employees to develop favorable affective and behavioral reactions to their job thereby increasing job satisfaction. Cohrs et al. (2006) examined the effects of self efficacy on job satisfaction and found a positive association. According to Bandura (1997) individual with high self efficacy will have greater job satisfaction because the feelings of competence and confidence that accompany self efficacy make the job more enjoyable (Purwanto, 2002). Therefore, it is hypothesized that:

Hypothesis-4: Job autonomy is positively related to job satisfaction, self efficacy as an intervening variable.

Job autonomy, Self Efficacy and Job Stress

Some researchers suggest that the need for personal control may be an intrinsic, ongoing desire (Elsass and Veiga, 1997). Although the need for personal control appears to vary among individuals, as well as across time and situations in a single individual, it may be that a desire for personal control is an inherent motivation Therefore, when individual loss of control in her/ his work (low job autonomy), it will associated with increased level of stress.

Previous researches have documented compelling evidence linking how level of job autonomy with the incidence of negative stress-related outcomes. High job autonomy will leads to reducing job stress because the presence of control may encourage individuals to believe positive outcomes are possible, thereby reducing feelings of threa (Spector, 1986; Elsass and Veiga, 1997). Karasek (1979) examined the effects of job control and level of depression and the result show that job control has a negative association with employees' leve of depression. The higher job autonomy, the lowe level of stress he/she have. This condition happens because high autonomy allows employees to carry out the job the way he/she wishes to and lead to reducing feelings of threat. Therefore, a negative linkage is hypothesized between job autonomy and job stress.

Hypothesis 5: Job autonomy is negatively related to job stress.

The literature suggests that people's perception on job autonomy enhance their self efficacy because this autonomous job allows people to use their skill, knowledge, and creativity to choose and formulate sales strategies without others' interference. According to Bandura (1997), people with high self efficacy will more likely to persist when encountering obstacles or negative experiences. Therefore, it is hypothesized that:

Hypothesis-6: Job autonomy is negatively related to job stress, self efficacy as an intervening variable.

\section{Job Satisfaction and Job Performance}

Perhaps the most controversial issues that have evolved from behavior research is the job satisfaction and job performance relationship. Previous researchers identified the following viewpoints that have been assumed by theorists with respect to the satisfaction and performance relationship. First, satisfaction causes performance. Second, performance causes satisfaction. Third, the satisfaction and performance relationship is moderated by a number of other variables.

Meta analysis conducted by Petty et al. (1984) found that the first viewpoint (satisfaction causes performance) is stronger and more consistent than others viewpoints. Engko (2006) also support this finding; job satisfaction found has a significant and positive effect on job performance with path coefficient 0,252 . Therefore, it is hypothesized that:

Hypothesis -7: Job autonomy is positively related to job performance

\section{Job Stress and Job Performance}

Understanding job stress is a major concern

of organization research because it has been shown to play a role in a number of key jobrelated attitudes (organizational commitment, job satisfaction) and behavior, such as turnover (Sager, 1994). Moreover, stress can lead to physical illness and chronic diseases such as heart disease, mental ill-health, depression or other problems such as alcoholism (Eckles, 1987 in Moncrief et al. 1997).

Narayanan et al. (1999) examined stressful incidents at work for three different occupations (clerical workers, university professors and sales associates). Lack of control and work overload were reported as major stressors by clerical group and interpersonal conflict as a major stressor by the academic and sales group. Gender differences in stress were also found in this research. Therefore, it can be conclude that stress occurred in all kind of job and affects the individual, group and organization's performance. Therefore, it is hypothesized that:

Hypothesis -8: Job stress is positively related to job performance

\section{METHODS}

Sample and Data Collection

Data were obtained from banking salesperson in Yogyakarta and Solo, Indonesia. Purposive sampling is used as sampling method so several criteria was applied to this study. The respondents have been working with those companies for more than 3 months. According to Gist and Mitchell (1992), judgments about self efficacy become more routinized and automatic as experience with a task increases. Therefore, setting 3 months as a criterion is relevant in reducing bias in answe self efficacy, job satisfaction, job stress an job performance. A total of 230 questionnaires were distributed to the salesperson directly through coordination with supervisor and area sales manager. A total 190 questionnaires with complete responses were returned directly to the researcher. Therefore, the response rate in this study is $89,13 \%$.

The average age of the respondents was 26-35 years, 56,3 percent of the respondents were male and 67,9 percent received a 4 -years college degree

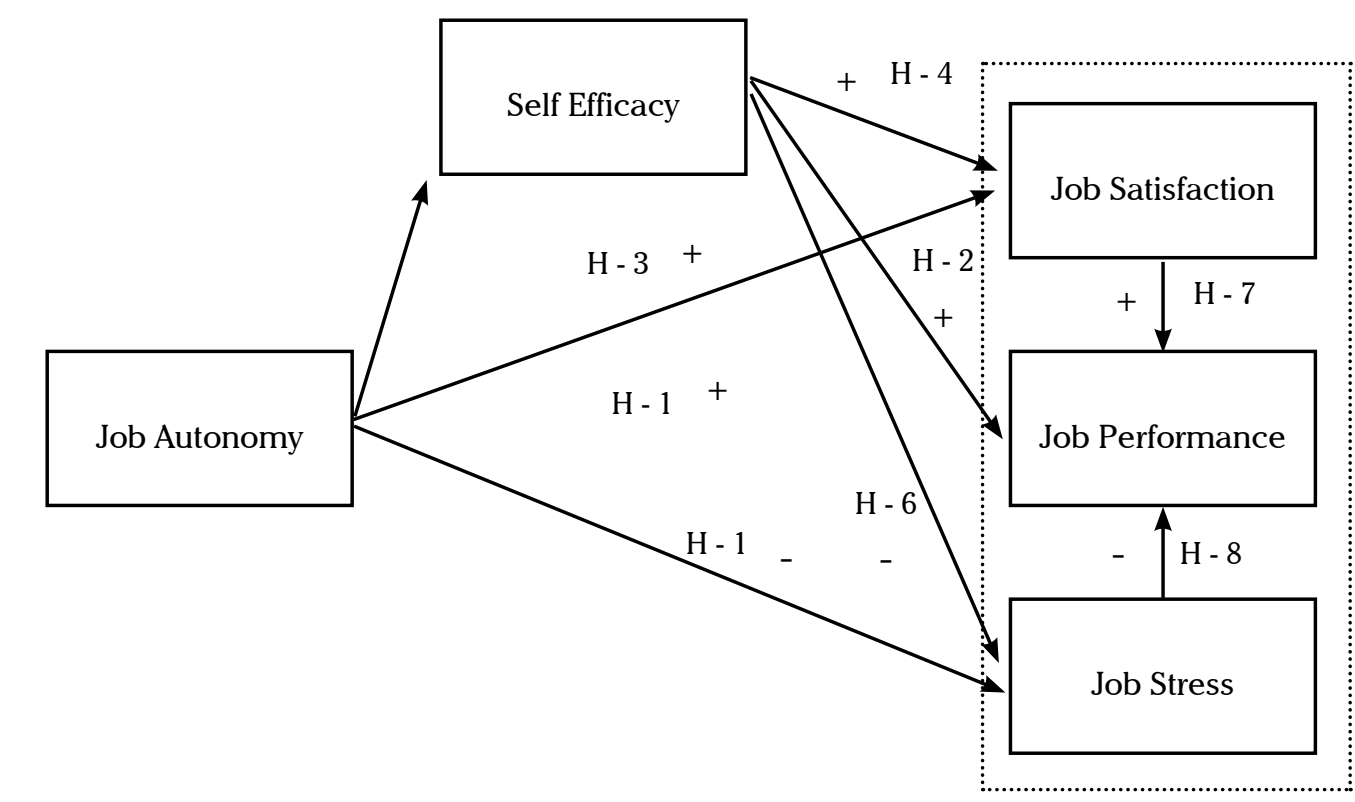

Figure 1. Research Model 
or higher education. The respondents have been affiliated with the companies for an average of 2 years, and their range selling experience was $2-6$ years.

This study used Structural Equation Modeling (SEM) to examined proposed model on figure 1. Samples used in this research are 190 salespersons and this amount are not meets the requirement of MLE based on total amount of estimated parameters (minimal 335 samples). This lackness will effects on identification model process. Therefore, researcher used two step approach on SEM which each construct will be composite first so tota amount of estimated parameter can be reduced based on total amount of sample collected.
Data analysis was conducted in two stages. First, checking for data entry includes validity and reliability, identification outliers and normality of the data. Second, testing of the fit model was conducted by using Structural Equation Modelling (SEM). Two-Step Approach to Structural Equation Modelling (SEM) was used to test the proposed model presented in figure 1. AMOS 4.01 computer program was utilized to run data from questionnaires. Goodness of fit model was based on multiple indices, selected from: the chi-square value and chi-square over degree of freedoms (normed Chi-Square), the Goodness of Fit Index (GFI), the Adjusted Goodness of Fit Index (AGFI), the Root Mean Square Error of Approximation (RMSEA).

Tabel 1. Operationalization Each Variables

\begin{tabular}{|c|c|c|c|c|c|}
\hline NO & Variables & Operasionalized & Measurement & $\begin{array}{l}\text { Amount of } \\
\text { items }\end{array}$ & Sample Item \\
\hline 1 & Job Autonomy & $\begin{array}{l}\text { The extent to which a } \\
\text { job allows the freedom, } \\
\text { independence and } \\
\text { discretion to schedule } \\
\text { work, make decision and } \\
\text { select the methods used } \\
\text { to perform tasks. }\end{array}$ & $\begin{array}{l}\text { James Breaugh's } \\
\text { Instrument: (1999)- } \\
\text { Work Autonomy } \\
\text { Scales }\end{array}$ & 9 items & $\begin{array}{l}\text { I am free to choose } \\
\text { the methods the } \\
\text { methods to use in } \\
\text { carrying out my } \\
\text { work". }\end{array}$ \\
\hline 2 & Job Performance & $\begin{array}{l}\text { Individual achievement } \\
\text { that regulated based on } \\
\text { organization's standard } \\
\text { and regulation }\end{array}$ & $\begin{array}{l}\text { Instrument of Miao } \\
\text { dkk. (2007) }\end{array}$ & 4 items & $\begin{array}{l}\text { "I am very effective } \\
\text { in contributing to } \\
\text { my firm's market } \\
\text { share". }\end{array}$ \\
\hline 3 & Job Satisfaction & $\begin{array}{l}\text { a pleasurable or positive } \\
\text { and negative emotional } \\
\text { states resulting from the } \\
\text { appraisal of one's job in } \\
\text { organization. }\end{array}$ & $\begin{array}{l}\text { Dubinsky dan } \\
\text { Hartley's Instrument } \\
\text { (1986) }\end{array}$ & 5 items. & $\begin{array}{l}\text { "I am generally } \\
\text { satisfied with the } \\
\text { kind of work I do in } \\
\text { this job". }\end{array}$ \\
\hline 4 & Job Stress & $\begin{array}{l}\text { A mental and } \\
\text { physical condition } \\
\text { which affects an } \\
\text { individual's productivity, } \\
\text { effectiveness, personal } \\
\text { health and quality of } \\
\text { work in organization. }\end{array}$ & $\begin{array}{l}\text { Instrument of House } \\
\text { dan Rizzo (1972). }\end{array}$ & 7 items & $\begin{array}{l}\text { "I often take my } \\
\text { work home with me } \\
\text { in the sense that I } \\
\text { think about it when } \\
\text { doing other things". }\end{array}$ \\
\hline 5 & Self-Efficacy & $\begin{array}{l}\text { Individual's belief in his } \\
\text { or her ability to perform } \\
\text { job-related tasks. }\end{array}$ & $\begin{array}{l}\text { Instrument of } \\
\text { Bandura (1977) }\end{array}$ & 8 items. & $\begin{array}{l}\text { "I feel I am } \\
\text { overqualified for the } \\
\text { job I will be doing". }\end{array}$ \\
\hline
\end{tabular}

\section{RESULTS AND DISCUSSION}

Validity and Reliability of Measures

Confirmatory Factor Analysis was used to asses the validity of each construct. Items with factor loading 0.4 or greater are considered practically significant (Hair et al. 2006). Results of Confirmatory Factor Analysis asserted that final items used in this study are 29 items. Cronbach's Alpha coefficients were used to estimate the reliability of each indicator in this research. Although, there was a difference criteria in Cronbach's Alpha coefficients, this research used 0, 6 as a criteria. According to Hair et al. (2006) this value is threshold to accept. Table 2 provides the reliability of the measures.

\section{Descriptive Statistic and Correlation}

\section{between Construc}

Descriptive statistic in this research involved mean, standard deviation and correlation between construct. Table 3 provides the descriptive statistic and correlation between construct. Result showed that job autonomy, self efficacy, job satisfaction and job performance correlate and significant in 0.01 while there is no correlation existed between job stress and other construct.

\section{Fixing the Error Terms and the Lambdas}

This study used two-step approach to test the proposed model in figure 1. Testing structural model using two-step approach requires value of lambda $(\lambda)$ and epsilon $(v)$. The measuremen error (epsilon) terms were fixed at (1-a) $\mathrm{X}$ variance and the corresponding lambdas-the loading from latent construct to its corresponding indicator were fixed at (alpha) $2 \mathrm{X}$ standard loading deviation. The lambdas and epsilon of the constructs are presented in table 4

Tabel 2. Reliability Coefficients (Cronbach's Alpha) of the Construct

\begin{tabular}{lccc}
\hline Construct & $\begin{array}{c}\text { Number of items in the } \\
\text { questionnaire }\end{array}$ & $\begin{array}{c}\text { Number of item } \\
\text { retained }\end{array}$ & Cronbach's Alpha \\
\hline Job Autonomy & 9 items & 9 items & 0.915 \\
Self Efficacy & 8 items & 6 items & 0.868 \\
Job Satisfaction & 5 items & 3 items & 0.608 \\
Job Stress & 7 items & 7 items & 0.809 \\
Job Performance & 4 items & 4 items & 0.914 \\
\hline
\end{tabular}

Tabel 3. Alphas ( $\alpha$ ), lambdas $(\lambda)$ and Epsilon (v)

\begin{tabular}{llcccc}
\multicolumn{1}{c}{ Variables } & \multicolumn{5}{c}{ Correlation Coefficient } \\
\cline { 2 - 6 } & OTO & \multicolumn{1}{c}{ SE } & \multicolumn{1}{c}{ KK } & SK & \multicolumn{1}{c}{ K } \\
\hline Job Autonomy (Oto) & 1,00 & $.593^{* *}$ & $.347^{* * *}$ & .005 & $.500^{* *}$ \\
Self Efficacy (SE) & & 1,00 & $.451^{* *}$ & -.014 & $.485^{* *}$ \\
Job Satisfaction (KK) & & & 1,00 & -.046 & $.379^{* * *}$ \\
Job Stress (SK) & & & & 1,00 & -.012 \\
Job Performance (K) & & & & & 1,00 \\
\hline Mean & 5.7754 & 5.2509 & 4.8193 & 3.5301 & 5.2263 \\
Std. DeviasiMinimum & .96174 & 1.17973 & 1.14528 & 1.18165 & 1.16330 \\
Maximum & 1.00 & 1.00 & 1.00 & 1.43 & 1.50 \\
& 7.00 & 7.00 & 7.00 & 7.00 & 7.00 \\
\hline
\end{tabular}

* Significant correlation at the level 0,0

ОTO= Job Autonomy; SE= Self Efficacy; KK= Job Satisfaction; SK= Job Stress; K= Job Performance 
Tabel 4. Reliability Coefficients (Cronbach's Alpha) of the Construct

\begin{tabular}{lccc}
\hline Construct & Alpha $(\boldsymbol{\alpha})$ & Lambda $(\boldsymbol{\lambda})$ & Epsilon $(\boldsymbol{v})$ \\
\hline Job Autonomy & 0,92 & 0,72 & 0,061 \\
Self efficacy & 0,87 & 0,87 & 0,71 \\
Job Satisfaction & 0,63 & 0,34 & 0,27 \\
Job Performance & 0,92 & 0,95 & 0,11 \\
\hline Job Stress & 0,82 & 0,76 & 0,24 \\
\hline
\end{tabular}

Tabel 5. Structural Model Equation Results

\begin{tabular}{lccc}
\hline \multicolumn{1}{c}{ Indices } & Cut of value & Result & Remarks \\
\hline$\left.\chi^{2}\right)-$ Chi-square & expected to be smaller & 0.494 & Marginal \\
Significance Probability & $\geq 0,05$ & 0.482 & Marginal \\
RMSEA & $\leq 0,08$ & 0.000 & Good \\
GFI & $\geq 0,90$ & 0.999 & Good \\
AGFI & $\geq 0,90$ & 0.984 & Good \\
CMIN/DF & $\leq 2,00$ & 0.494 & Good \\
TLI & $\geq 0,90$ & 1.026 & Good \\
CFI & $\geq 0,90$ & 1.000 & Good \\
NFI & $\geq 0,90$ & 0.998 & Good \\
\hline
\end{tabular}

\section{Test of the Structural Model}

Table 4 interpret the test of structural model proposed. Goodness of fit model was assessed base on multiple indices. The result showed that the model proposed is acceptable and has a good fit (table 5).

\section{Test of Structural Relationship}

After the criteria of goodness of fit have been fulfilled, the test of structural relationship is conducted. The relationship between constructs in output AMOS 4.01 showed by value of standardized regression weight. According to Hair et al. (2006) structural relationship is significant if estimate parameter more than 1, 96 (significance level 0.05 ) and $\geq 2,58$ (significance level 0,01 ). Regression weight model in this research provide in table 6 .

Table 6 showed that critical ratio (CR) for relationship between job autonomy and job performance is 2, 795 (significant at $\alpha=0.01$ ). It indicated that hypothesis 1 is supported; job autonomy significantly positive related to job performance. Similarly, the test showed a strong support for $\mathrm{H}-2$. Critical ratio for relationship between job autonomy and self efficacy is 9 . 459 and self efficacy on performance is 2.151 . It means that, self efficacy partially mediated the relationship between job autonomy and job performance. This study also support hypothesis 3 ; CR for job autonomy on job satisfaction is 2.097 (significant at $\alpha=0.05$ ). It indicated that the higher level of job autonomy, the higher level of job satisfaction. Critical ratio for job autonomy on self efficacy, and self efficacy on job satisfaction also significant at 0,01 . Therefore, self efficacy partially mediated the relationship between job autonomy and job satisfaction ( $\mathrm{H}-4$ supported).

Furthermore, critical ratio for job autonomy on job stress is 0,079 and it lower than criterion required. Therefore, this research did not support hypothesis 5 . It indicated that there is no significant relationship existed between job autonomy and job stress. Similarly, CR for job autonomy on self

Tabel 6. Regression Weights

\begin{tabular}{|c|c|}
\hline Structural Relationship & Critical Ratio \\
\hline selfefficacy <--------autonomy & $9.459 *$ \\
\hline jobsatisfaction <----selfefficacy & $3.680^{*}$ \\
\hline jobsatisfaction <------ autonomy & $2.097^{* * *}$ \\
\hline jobstress <------selfefficacy & -0.240 \\
\hline jobstress <--_------ autonomy & 0.079 \\
\hline jobperformance <-------jobsatisfaction & $2.345^{* *}$ \\
\hline jobperformance <--------jobstress & -0.043 \\
\hline jobperformance <---------selfefficacy & $2.151^{* *}$ \\
\hline jobperformance <-_-_----a-autonomy & $2.793^{*}$ \\
\hline
\end{tabular}

* Significant at $\alpha=0.01 ; *$ * Significant at $\alpha=0.05$

efficacy is 9,459 (significant at 0,01 ) and CR for self efficacy on job stress 0,240 (not significant). Based on this, this research did not support hypothesis 6. Self efficacy did not mediate the relationship between job autonomy and job stress.

In addition, this research supports the hypothesis 7. The results showed that critical ratio for job satisfaction on job performance is 2,345 (significant at 0,05 ). The higher job satisfaction, the higher job performance. Table 5 also showed that $\mathrm{CR}$ for job stress on job performance is 0,043 and lower than 1, 96 (not significant). So, it can be conclude that there is no significant relationship existed between job autonomy and job performance.

This research's result showed that job autonomy positively related to performance. This finding support the study conducted by Gellatly and Gregory (2001). The higher salesperson perceives job autonomy will lead to increasing job performance. Job autonomy affects salesperson's performance because through job autonomy, salesperson granted responsibility and independence to perform their work. Psychologically, salesperson will more motivate which in turn leads to outcomes such as high self efficacy. According to Bandura (1997) individual with high self efficacy will put forth more effor to attain the best performance. Therefore, similar with the result, self efficacy partially mediated job autonomy on job performance (H-2 supported).

This research also support that job autonomy positively related to job satisfaction. This result support the study conducted by Morrison et al. (2005) which found that job autonomy became an important factor for employee's job satisfaction. High autonomy affects salesperson's perception about their job. They will fell that the results of their job are determined by their efforts, actions and decisions. This condition changes their judgement of self efficacy and behavior in performing the job which leads to increasing self efficacy and job satisfaction. Therefore, we can conclude that job autonomy enhance job satisfaction through self efficacy (H-4 supported).

Job autonomy negatively related to job stress (Elsass and Veiga, 1997; Karasek, 1979; Spector 1979). Job autonomy allows salesperson to carry out the job with the way he/she wishes to which leads to reducing feeling of threat. This condition creates a comfortable work environment and 
reducing job stress. This research did not support this relationship. There is no significant relationship existed between job autonomy and job stress. Table 2 reported that salesperson's job stress is lower than other variables (autonomy, satisfaction, performance and self efficacy). This research also did not find the role of self efficacy in mediated job autonomy on job stress.

This inconsistency result occurred because of several factors. First, there are many antecedents of job stress. Salespersons might be exposed to the same stressors but they experience different stress levels or different stress symptoms. This happens because of individuals differences. Each of salespersons perceives the same situation differently. Each salesperson also has different thresholds of resistance to a stressor and differen way to coping stressors (Greenberg and Baron, 2003). These individual difference may be the causes inconsistency the relationship between job autonomy and job stress. Second, job experience may be effects the level of salesperson's job stress. Based on respondent's demography in this research, $34,21 \%$ of salespersons have been working as a salesperson for 2 until 6 years while $31,57 \%$ have been working less than two years.

Job experience enhances salesperson's belie that he or she has the ability to complete a task and coping the stressors successfully. Gist and Mitchell (1992) state that judgments about self efficacy become more routinized and automatic as experience with a task increases. Third, each salesperson has a difference perception on stressful circumstance. Stress involves people's cognitive appraisal of the potential stressors they face (Greenberg and Baron, 2003). Job autonomy shapes important factor in influencing salesperson's behavior, namely self efficacy. Self efficacy changes salesperson's perception abou stressful circumstance. Salespersons perceive stressors as challenge rather than threat in work This condition may be the causes of insignificance the role of self efficacy in mediated the relationship between job autonomy and job stress.

The testing of seventh hypothesis showed that job satisfaction positively related to job performance. Satisfied salesperson will put forth more effort and leads to increasing job performance. This result support Engko's (2006) study which states that satisfied worker is an effective worker. Finally, this research did not found significant relationship between job stress and performance (H-7). A Meta analytic test by Lepine et al. (2005) report that inconsistent relationship among stress and performance is occurred because of previous researches did not distinguishes among positive and negative stress. Positive stress (challenge stress) is a stressful demands viewed by manager/ organization as obstacles to be overcome in order to learn and achieve. Negative stress (hindrance stress) is a stressful demands viewed by manager/ organization as unnecessarily thwarting personal growth and goal attainment. Therefore, Lepine et al. (2005) suggests that in further research stress must be distinguishes positive and negative stress. In this research stress is treated as negative stress and it may cause the insignificance of job stress on job performance.

\section{MANAGERIAL IMPLICATIONS}

This research has an important implication to managers in designing job. Specifically, the implication designed to banking sector due to recentresearch contects. First, granthighautonomy will lead to increasing intrinsic motivation thereby increasing self efficacy, job performance and satisfaction. Consequently, managers must grant salesperson the freedom in performing the job in two facets; work method autonomy and work schedule autonomy. Second, the significance of job satisfaction in job performance has been shown by this study. Consequently, manager must find way to increase salesperson's job satisfaction. Job satisfaction can be increase by granting job autonomy, provide a conducive work environments through reward and punishment system, physical work environment, facility, social support, and supervisor support.

\section{Limitation and Futher Study}

There are four limitations worth noting in this study. First, this investigates is limited in scope of banking salesperson's which reducing in external validity. So, in further study should involve other salespersons in different industry. Second, the final sample used in this study is relatively small which causes in difficulties fitting models with data. As a consequently, the research conducted two step approach to estimate the model proposed. Third, a self-report job performance measure was used in this study. This may be contained bias in capture the phenomena. So, in further study objective performance measure or multi-rater should be used to assess the job performance. Forth, this research treats stress as a negative stress and did not distinguish between negative and positive stress. However, researcher have been interviewed the supervisor, area sales manager and several salespersons to get the phenomena about stress in their workplace.

\section{CONCLUSION}

The purpose of this research is to examine the relationship between job autonomy and work outcomes (job performance, job satisfaction and job stress), self efficacy as a mediating variable. This research also investigates the impact of job satisfaction on job performance and job stress on job performance. Based on the results, can be concluding that:

1. Structural model estimated in this research acceptable fit to the data. It can be seen in several criterion of goodness of fit, such as: Chi-Square $(0,494)$; Significance Probability $(0,482) ;$ RMSEA $(0,000)$; GFI $(0,999) ;$ CMIN/DF $(0,494)$; TLI $(1,026)$; CFI $(1,00)$; NFI $(0,998)$.

2. Job autonomy positively related to job performance and satisfaction. The higher autonomy will leads to increasing salesperson's job performance and job satisfaction.

3. Self efficacy partially mediated the relationship between job autonomy and job satisfaction, and relationship between job autonomy performances.

4. Job autonomy did not relate to job stress. Self efficacy also did not mediate the relationship between job autonomy and job stress. Individual difference may be the causes of insignificant this relationship.

5. Job satisfaction positively related to job performance. Satisfied salespersons will positively effects their intrinsic motivation and the effectiveness in working.

6. Job stress did not relate to job performance. This condition happens because this research did not distinguish between negative an positive stress which lead to bias. 
Denton, David W. \& Lawrence S. Kleiman (2001). Job Tenure as a Moderator of The Relationship Between Autonomy and Satisfaction. Applied H.R.M. Research. Vol. 21, No. 2, pg. 105-114.

DeCarlo, Thomas, E. \& Sanjeev Agarwal (1999). Influence of Managerial Behaviors and Job Autonomy on Job Satisfaction of Industrial Salespersons. Industrial Marketing Management. Vol. 28, pg. 51-62.

Engko, Cecilia (2006). Pengaruh Kepuasan Kerja Terhadap Kinerja Individual Dengan Self-Esteem dan Self-Efficacy sebagai

Elsass, Priscilla M. \& Veiga, John F. (1997). Job Control and Job Strain: A Test of Three Models. Journal of Occupational Health P.

Finn, C.P. (2001) Autonomy: an important component for nurses' job satisfaction. International Journal of Nursing Studies.

Gellatly, Ian R. \& Irving P., Gregory (2001). Personality, Autonomy and Contextual Performance for Managers. Human Performance, Vol.43, No.3, pg. 231-245

Gist, Marilyn E., \& Terence R. Mitchell. (1992). Self-efficacy: A Theoritical Analysis of Its Determinants and Malleability. Academy of Management Review. Vol. 17, №. 2, pg. 183-211

Hair, J. F. J.; Anderson, R.E;; Tatham, R.L. \& Black, W.C. (2006). Multivariate Data Analysis, $6^{\text {th }}$ edition. Upper Saddle River, Prentice Hall International, Inc

Karasek, R. A. (1979). Job Demands, Job Decision Latitude and Mental Strain: Implications for Job Redesign. Administrative Science Quarterly. Vol. 24. pg. 285-310.

Kauffeld, Simone. (2006). Self-directed Work Groups and Team Competence. Journal of Occupational and Organizational Psychology. Vol. 79, pg. 1-21.

Kreitner, Robert and Angelo Kinicki (2004). Organizational Behavior. $6^{\text {th }}$ edition. McGraw Hill Companies, Inc.

Langfred, Claus W. \& Moye Neta, A. (2004). Effects of Task Autonomy on Performance: An Extended Model Considering Motivational, Informational and Structural Mechanisms. Journal of Applied Psychology, Vol.89, No.6, 934-945

LePine, Jeffery; Podsakoff, Nathan \& LePine, Marcie. (2005). A Meta Analytic Test of The Challenge Stressor-Hindrance
Stressors Framework: An Explanation For Inconsistent Relationships Among Stressors and Performance. Academy of Management Journal. Vol. 48, No. 5, pg. 764-775.

Liu, Cong; Spector, Paul E.; Jex, Steve (2005). The relation of job control with job strains: A comparison of multiple data sources. Journal of Occupational and Organizational Psychology. Vol. 78 pg. 325-336

Miao, C. Fred; Evans, Kenneth R. \& Zou, Shaoming. (2007). The Role of Salesperson Motivation in Sales Control SysytemIntrinsic and Extrinsic Motivation Revisted. Journal of Business Research. Vol. 60, pg. 417-425.

Moncrief, William; Babakus, Emin; Craven, David \& Johnston, Mark. (1997) Examining the Antecedents and Consequences of Salespersons Job Stress. European Journal of Marketing. Vol. 31, No. 11/12, pg. 786-798

Morrison, David; Cordery John; Antonia Girardi \& Roy Payne (2005). Job design, Opportunities For Skill Utilization and Instrinsic Job Satisfaction. European Journal of Work and Organizational Psychology. Vol. 14, No.1, 59-79

Narayanan, Lakshmi; Menon, Shanker \& Spector, Paul E. (1999). Stress in the Workplace: A Comparison of Gender and Occupations. Journal of Organizational Behavior. Vol. 20, No. 1, pg. 63-73

Nguyen, Anh Ngoc., Jim Taylor \& Steve Bradley. (2003). Job Autonomy and Job Satisfaction: A New Evidence. Working Paper. Petty, M.M., Gail, W. McGee \& Jerry W. Cavender (1984). A Meta Analysis of The Relationship Between Individual Job Satisfaction and Individual Performance. Academy of Management Review. Vol. 9, No. 4, pg. $712-721$.

Sager, J.K. (1994). A Structural Model Depicting Salespeople’s Job Stress. Journal of The Academy Of Marketing Science. Vol. 22, No. 1. pg. 74-84.

Simmering, Marcia, J.; Noe, Raymond, A; Colquitt, Jason, A.; Porter, Christopher (2003). Conscientiousness, Autonomy Fit and Development: A Longitudinal Study. Journal of Applied Psychology, Vol. 88, No. 5. pg. 954-963

Singelmann, Joachim, \& Mencken F. Carson (1992). Job Autonomy and Industrial Sector in Five Advanced Industrial Coountries. Social Science Quarterly, Vol.73, No. 4.

Smith, Eugene Sadler, Ghada El-Kod; Mike Leat (2003). Differentiating work autonomy facets in a Non-Western Context. Dal Behavior. Vol.24, Iss.6, pg. 709

Spector, P. E. (1986). Perceived Control by Employee: A Meta-analysis of studies concerning autonomy and participation at work. Human Relations. Vol. 39. pg. 1005-1016.

Thompson, Cynthia A., \& David J. Prottas (2005). Relationship Among Organizational Family Support, Job Autonomy, Perceived Control, and Employee Well-Being. Journal of Occupational Health Psychology. Vol. 10, No. 4, pg. 100-118.

Wang, Guangping \& Netemeyer, Richard (2002). The Effects of Job Autonomy, Customer Demandingness, and Trait Competitiveness on Salesperson Learning, Self efficacy and Performance. Journal of The Academy of Marketing
Science Vol 30 . No 3 . $217-228$.
Appendix

Please check list to the one number which best describe your condition.

\begin{tabular}{ccccccc}
\hline 1 & 2 & 3 & 4 & 5 & 6 & 7 \\
\hline $\begin{array}{l}\text { Strongly } \\
\text { disagree }\end{array}$ & Disagree & $\begin{array}{c}\text { Rather } \\
\text { disagree }\end{array}$ & Neutral & $\begin{array}{c}\text { Rather } \\
\text { agree }\end{array}$ & Agree & $\begin{array}{c}\text { Strongly } \\
\text { agree }\end{array}$ \\
\hline
\end{tabular}

\begin{tabular}{lccccccc}
\hline JOB AUTONOMY & 1 & 2 & 3 & 4 & 5 & 6 & 7 \\
\hline $\begin{array}{l}\text { Iam allowed to decide how to go about getting my job done (the } \\
\text { methods to use) }\end{array}$ & $\square$ & $\square$ & $\square$ & $\square$ & $\square$ & $\square$ & $\square$
\end{tabular}

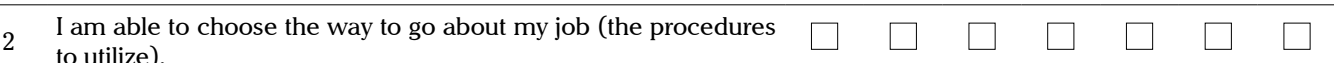

$\begin{array}{lllllll}3 \quad \text { I am free to choose the methods to use in carying out my work } & \square & \square & \square & \square & \square \quad\end{array} \quad \square$

$4 \quad$ I have control over the scheduling of my work

\begin{tabular}{ll}
$5 \quad \begin{array}{l}\text { I have some control over the sequencing of my work activities } \\
\text { (when I do what). }\end{array}$ \\
\hline 6
\end{tabular}

\begin{tabular}{ll}
\hline$\quad \begin{array}{l}\text { My job is such that can decide when to do particular work } \\
\text { activities. }\end{array}$ & $\square \quad \square \quad \square \quad \square \quad \square \quad \square$
\end{tabular}

$\begin{aligned} & \text { My job allows me to modify the normal way we are evaluated } \\ & \text { so that I can emphasize some aspects of my job and play down } \\ & \text { others }\end{aligned} \quad \square \quad \square \quad \square \quad \square \quad \square \quad \square$

\begin{tabular}{ll}
$8 \quad \begin{array}{l}\text { I am able to modify what my job objectives are (what I am } \\
\text { supposed to accomplish). }\end{array}$ \\
\hline
\end{tabular}

I have some control over what I am supposed to accomplish
(what my supervisor sees as my job objectives) $\quad \square \quad \square \quad \square \quad \square \quad \square \quad \square$

\begin{tabular}{llllllll} 
(what my supervisor sees as my job objectives) & 1 & 2 & 3 & 4 & 5 & 6 & 7 \\
\hline SELF-EFICACY & & & & & & & \\
\hline
\end{tabular}

$\frac{\text { SELF-EFFICACY }}{1 \quad \text { My new job is well within the scope of my abilities }}$

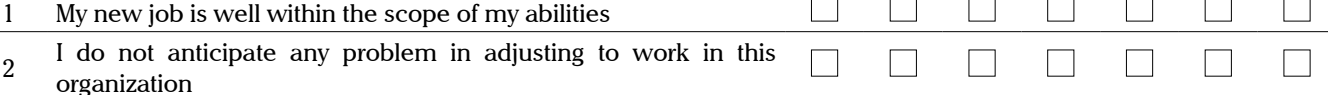

3 I feel I am overqualified for the job I will be doing $\quad \square \quad \square \quad \square \quad \square \quad \square \quad \square \quad \square$
4

\begin{tabular}{llllllll}
4 & $\begin{array}{l}\text { Ihave all the technical knowledge Ineed to deal with my new job, } \\
\text { all I need now is practical experience. }\end{array}$ \\
\hline 5
\end{tabular}

If fell confident that my skill and abilities equal or exceed those of
my future colleagues $\quad \square \quad \square \quad \square \quad \square \quad \square \quad \square$

My past experiences and accomplishments increase my
confidence that I will be able to perform successfully in this $\square \square \square \square \square \square \square \square$

I could have handled a more challenging job than the one I will $\square \quad \square \quad \square \quad \square \quad \square \quad \square \quad \square$
be doing

Professionally speaking, my new job exactly satisfies my
expectations of my self (R) $\quad \square \quad \square \quad \square \quad \square \quad \square \quad \square$

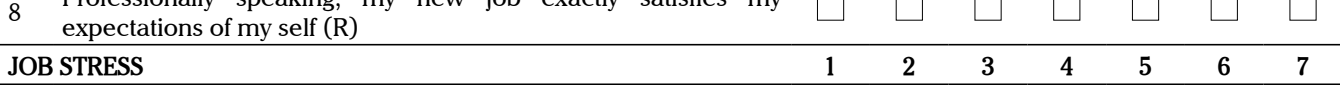

\begin{tabular}{ll}
\hline JOB STRESS \\
\hline 1 I feel fidgety or nervous because of my job
\end{tabular}

2 Problems associated with work kept me awake at night

My job tends to directly affect my heal

Thad a different job, my health would probably improve $\quad \square \quad \square \quad \square \quad \square \quad \square \square \square$

5. it when doing other things
6 .

$\begin{array}{lllllll}6 & \text { If fell nervous before attending meetings in the organization } & \square & \square & \square & \square & \square\end{array}$

7 I sometimes feel weak all over

$8 \quad$ I feel fidgety or nervous because of $\mathrm{my} \mathrm{job}$

JOB PERFORMANCE

$1 \quad$ Iam very effective in contributing to my firm's market share

$\frac{2}{2}$ I am very effective in generating a high level of dollar sales

$3 \quad$ I am very ellective in sellingto najor accoun

$4 \quad$ Iam very effective in exceeding annual sales targets and objectives

JOB SATISFACTION
1 Generally speaking, I am very satisfied with this job

\begin{tabular}{cl}
2 & Ifrequently think of quiting this job (reverse-coded) \\
\hline 3 & I am generally satisfied with the kind of work I do in this jo
\end{tabular}

4 Most people on this job are very satisfied with this job

5 People on this job often think of quitting (reverse-coded) 